\title{
Percursos e percalços do sargento Prestes de Paula: trajetória de um militar comunista em busca de entrosamento social no Brasil republicano.
}

\author{
Lucas Porto Marchesini Torres*
}

Resumo: Recorrendo a variadas fontes (entrevistas, processos judiciais, arquivos de polícia, correspondências privadas, etc.) o artigo reconstrói a trajetória de Antônio Prestes de Paula (1927-2004). Em meados da década de 1940, Prestes atuava na juventude do PCB até ingressar na carreira militar, se afastando da militância político-partidária. Nos anos 1961-1963, foi uma liderança do Movimento dos Sargentos, quando se reaproximou do PCB. Liderou o levante dos sargentos (Brasília, 1963) e por isso terminou expulso da Aeronáutica e preso. Após o golpe de 1964, uniu-se na prisão a marinheiros e presos comuns para fundar o Movimento de Ação Revolucionária, grupo de luta armada contra a ditadura (1964-1985). Escapou em 1969 e se filiou ao Partido Comunista Brasileiro Revolucionário (PCBR). Por sua militância clandestina precisou exilar-se primeiro no Chile e depois na França. Em 1980 retornou ao Brasil, reassumindo suas atividades no PCBR e também se filiando ao Partido dos Trabalhadores. Prestes manteve essa dupla militância até que foi preso pelo envolvimento em assaltos a banco na Bahia.

Palavras-chave: Antônio Prestes de Paula; biografia; Brasil republicano; militares.

Abstract: Using various sources (interviews, lawsuits, police files, private correspondence, etc.) the article reconstructs moments of the trajectory of Antônio Prestes de Paula (1927-2004). In the mid-1940s, Prestes worked for the PCB youth before entering a military career, moving away from the political party militancy. In the years 1961-3 he was a leader of the Movement Sergeants when reconnected the PCB. Hed led the uprising of the sergeants (Brasilia, 1963) and for this he has been expelled from the Air Force and arrested. After the Coup of 1964 he joined marines and other ordinary prisoners in prison to found the Revolutionary

* Doutorando em História Social na Universidade Estadual de Campinas (Unicamp) e autor do livro Estratégias de uma esquerda armada. Militância, assaltos e finanças do PCBR na década de 1980. Salvador: Edufba, 2017 (no prelo). Agradeço aos pareceristas anônimos da Revista Mundos do Trabalho por suas importantes sugestões. E-mail: lucaspmt@hotmail.com. 
Action Movement, a group that wanted to expropriate an armed struggle group against dictatorship (1964-1985). He escaped in 1969 and he joined the Brazilian Revolutionary Communist Party (PCBR). Because of this clandestine militancy, he escaped to Chile and then to France. In 1980 he returned to Brazil, resuming activities within the PCBR and joining the Workers' Party. Prestes maintained this double militancy until he was arrested for involvement in bank robberies in Bahia.

Keywords: Antônio Prestes de Paula; biography; republican Brazil; military.

\section{Introdução}

Em abril de 1986, o nome de Antônio Prestes de Paula ocupou manchetes de jornais país afora após sua associação a uma tentativa de assalto a banco em Salvador. Num primeiro momento, cinco homens foram presos ao deixar a agência e revelaram suas motivações para aquilo que consideravam uma "ação": eram petistas e roubavam em prol da Nicarágua sandinista, o que chamou atenção da imprensa e das polícias Civil e Federal. Mais adiante, testemunhas confrontadas com uma foto de arquivo da Polícia Federal confirmaram sua presença no entorno do banco comandando a ação e ele foi considerado foragido. Como se vê, o passado de Prestes serviu como fio condutor das investigações, que logo descobriram a segunda militância daqueles presos no Partido Comunista Brasileiro Revolucionário (PCBR), algo que todos tentaram esconder. No final da década de 1960, o PCBR surgiu como um racha do Partido Comunista Brasileiro (PCB), defendendo a luta armada contra o regime ditatorial, e nos anos 1980 se reorganizou no Partido dos Trabalhadores (PT) como uma de suas diversas tendências, numa situação de semilegalidade. Dois meses após o assalto, Prestes foi capturado e se reuniu com seus companheiros. Antes da prisão, em 1986, Prestes e o mesmo grupo participaram de outros dois assaltos bem sucedidos na Bahia, um em 1984, outro em 1985. ${ }^{1}$

A participação do sexagenário Prestes de Paula no assalto em Salvador ilustra o paroxismo de duas características que o marcaram profundamente ao longo da vida: a disposição às ações armadas e a militância política vinculada ao comunismo. No final da adolescência, Prestes se alistou como sargento na Aeronáutica, mas antes disso já militava na juventude do PCB. Sua experiência militar o fez descobrir valores de classe que o tornaram líder de uma categoria que se sentia representada por ele: os subalternos das Forças Armadas. A conjuntura de tensões políticas do período que antecedeu o golpe de 1964 extremaram a posição de Prestes à frente dos sargentos e o levaram, primeiro à cadeia, depois à luta armada clandestina contra o regime ditatorial que se instalou no país. A partir de então, Prestes deixou de experimentar o entrosamento social de que dispunha como liderança militar e aprofundou-se em ideias e práticas ditas revolucionárias, muitas vezes isoladas e sem respaldo social.

1 Para atuação do PCBR nesse período, ver TORRES, Lucas Porto Marchesini. "'A questão financeira é uma questão política". Militantes do PCBR em ações armadas na Bahia (década de 1980)". (Dissertação de mestrado em História, Universidade Federal da Bahia, 2013). 


\section{Imagem 1}

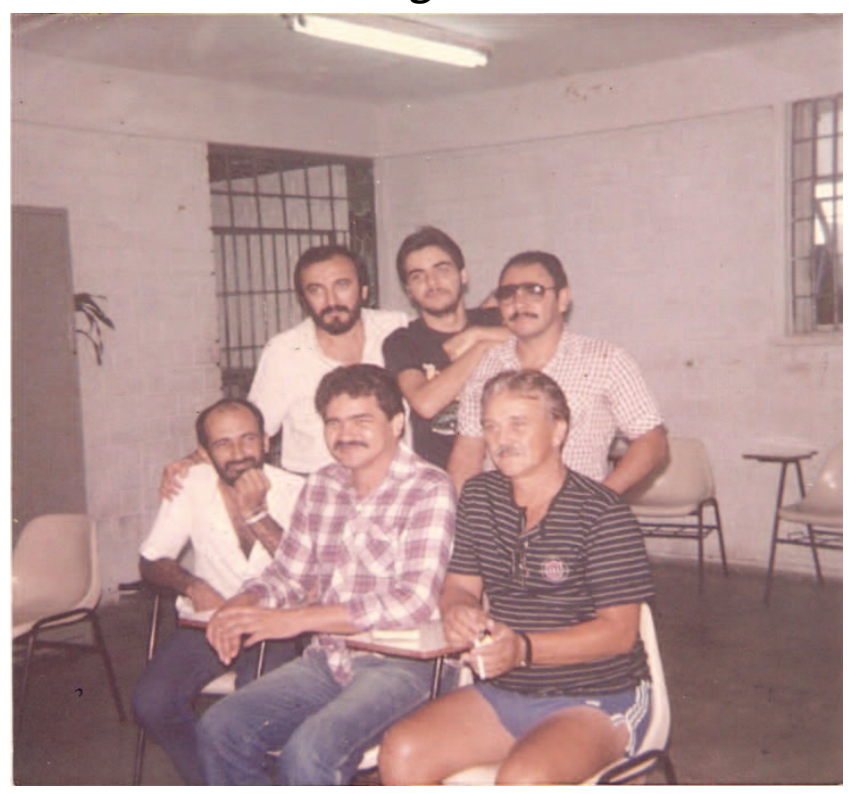

Foto do acervo familiar de Antônio Prestes de Paula. Após a captura de Prestes (sentado à direita, com cigarro na mão), em junho de 1986, o grupo de militantes do PCBR que tentou assaltar um banco em Salvador se reuniu novamente.

O presente artigo pretende demonstrar os limites e alcances da atuação de Prestes de Paula entre essas duas influências (experiência militar e militância comunista) e analisar como elas contribuíram para as relações que ele estabeleceu ao longo de sua trajetória, não raro produzindo conflitos. Sua vida na caserna e sua prática comunista estiveram sempre relacionadas com as diferentes redes sociais com que Prestes interagiu, entre companheiros de quartel, presídio ou de militância; entre oficiais superiores ou agentes da repressão. $O$ artigo examina $o$ papel que sua experiência de formação profissional encarnada nas vivências da caserna teve na sua formação, demonstrando o sujeito em tela no seu contínuo processo de amadurecimento nos diversos contextos em que se inseriu, com especial atenção às suas relações com os mundos do trabalho.

De acordo com Sabina Loriga, os estudos biográficos recuperaram fôlego a partir da busca por encontrar a agência de sujeitos subalternos, o que estimulou historiadores a se dedicarem não apenas às suas experiências coletivas, mas também às individuais. ${ }^{2}$ Por isso, o estudo de Loriga sobre a experiência militar ao longo dos séculos XVII e XX propõe questões que encontram ressonância na trajetória de Prestes de Paula. Segundo ela,

Na segunda metade do século XIX e na primeira década de nosso século (...) mesmo representando uma experiência de separação, o serviço militar não assumia ainda um valor iniciatório para todos. A esse respeito seriam necessárias pesquisas mais detalhadas sobre a percepção do Exército por parte da tropa, mas parece provável que para aqueles jovens que já trabalhavam desde algum tempo e haviam passado longos períodos longe dos pais, o chamado às armas não marcava a passagem de uma situação de dependência familiar para outra de independência. ${ }^{3}$

2 LORIGA, Sabina. "A biografia como problema". In: REVEL, Jacques (org.). Jogos de escalas. A experiência da microanálise. Rio de Janeiro: Fundação Getúlio Vargas, 1998, p. 225-226.

3 LORIGA, Sabina. "A experiência militar". In: LEVI, Giovani; SCHMITT, Jean-Claude (orgs.). História dos Jovens - A Época Contemporânea. Tradução: Nilson Moulin. São Paulo: Companhia das Letras, 1996, v. 2, p. 35. 
Prestes de Paula teve na Aeronáutica sua primeira experiência de trabalho e ela se tornou marcante em sua trajetória por ter garantido sua independência em diversos aspectos, conforme se verá. A percepção que o próprio Prestes demonstra ter sobre sua experiência militar é de que ela o fez amadurecer e descobrir valores que eram novos para ele, como experiências de classe, e outros nem tanto, como sua militância político-partidária. Sua trajetória é marcada por relações complexas e diversas, e a partir de sua análise é possível perceber conflitos típicos dos mundos do trabalho em diálogo com as análises de Loriga sobre a experiência militar.

\section{Primeiros anos}

Antônio Prestes de Paula nasceu em Campo Florido (MG) em 13 de junho de 1927. Uma segunda-feira ápice da trezena de Santo Antônio, de quem, segundo registrou o próprio, herdou o primeiro nome por devoção de sua mãe, dona Antonieta. ${ }^{4} \mathrm{O}$ segundo nome foi escolhido para agradar, em parte, a seu pai. Havia poucos meses que o Cavaleiro da Esperança, Luís Carlos Prestes, encerrara sua marcha pelo Brasil, depondo armas na Bolívia, e o farmacêutico Alfredo de Paula segundo o filho, "prestista fissurado, roxo" -, quis batizar o menino homenageando o líder a quem muito admirava. ${ }^{5}$ Se o gosto de seu Alfredo fosse respeitado por inteiro, o nome do garoto seria Luís Carlos Prestes de Paula. Porém, temerosa quanto ao ônus que o filho poderia carregar, a mãe contrariou-se. O menino foi batizado de modo a atender parcialmente a todos: Antônio Prestes de Paula. Uma versão definitiva em que o garoto pôde ficar com o Prestes do Cavaleiro da Esperança, como legara-lhe o pai, e dona Antonieta com a sua esperança de mãe.

No entanto, a influência do santo parece ter se limitado ao seu registro cartorial. Em 1937, seu Alfredo, o mais velho de quatorze irmãos, foi assassinado por envolver-se num triângulo amoroso e ainda cedo Prestes passou aos cuidados financeiros dos tios. Morto quando o filho tinha apenas dez anos de idade, seu Alfredo viveu o suficiente para acompanhar a conversão do Cavaleiro da Esperança ao comunismo. Conforme Prestes de Paula registrou em entrevista, o comunismo do pai nunca foi uma opção independente. Prestista roxo, seu Alfredo acompanhava os rumos do Cavaleiro da Esperança, filiado oficialmente ao PCB em 1934, mas desde 1927 - ano em que Prestes de Paula recebera seu nome - já se aproximava de ideias comunistas. ${ }^{6}$

Sob a influência direta que trazia do pai, fosse pelo nome que recebeu ou pelo exemplo, Prestes não demorou a filiar-se às ideias vermelhas. Após a morte de seu Alfredo, ele viveu como interno em um colégio da ordem Marista em Minas Gerais, para em seguida completar o curso científico no Rio de Janeiro, matriculado no Colégio Andrews. ${ }^{7}$ Prestes alega ter adquirido gosto pela política à medida que o Estado Novo do presidente Getúlio Vargas (1937-1945) perdeu

4 Entrevista de Prestes de Paula aos historiadores Muniz Ferreira e Sandra Silva, 4 ago. 2001, gentilmente disponibilizada a este pesquisador por Sandra Silva, a quem agradeço por sua cumplicidade acadêmica.

5 A marcha da Coluna Miguel Costa-Prestes, mais conhecida apenas pelo nome de Prestes, foi encerrada em fevereiro de 1927 após percorrer algo em torno de 25 mil quilômetros pelo país.

6 Os primeiros contatos de Luís Carlos Prestes com textos e ideias comunistas aconteceram ainda em 1927, conforme apontam suas recentes biografias: PRESTES, Anita Leocádia. Luiz Carlos Prestes: um comunista brasileiro. São Paulo: Boitempo, 2015, p. 103-104 e REIS, Daniel Aarão. Luís Carlos Prestes: um revolucionário entre dois mundos. São Paulo: Companhia das Letras, 2014, p. 113-114; porém, seu ingresso oficial no partido aconteceu apenas em 1934, às vésperas do putsh de 1935, como demonstram as mesmas.

7 Entrevista de Prestes de Paula, 4 ago. 2001. Fonte usada ao longo do parágrafo e também no seguinte. 
força. Militou na União Nacional dos Estudantes (UNE), entidade que segundo ele era bastante politizada: "Os secundaristas chegavam e discutiam coisas de Lênin, Marx, da Revolução Bolchevique. De um modo geral havia uma grande aceitação, um interesse muito grande da juventude pela revolução, sobretudo a Revolução Bolchevique", era o que pensava em 2001. Segundo a lógica de suas memórias, afeitas ao tema da revolução, do engajamento na UNE ao ingresso na juventude do PCB, foi uma sucessão natural.

Nesses anos em que viveu no Rio de Janeiro, Prestes de Paula atraiu-se não apenas pela efervescência política, mas despertou também para a necessidade de ingressar de vez no que entendia como "mundo adulto" - palavras dele -, arranjando um emprego que o permitisse romper com a tutela familiar. Prestes tentou ingressar no curso para mecânico de voo oferecido pela PanAir, companhia pioneira no ramo da aviação civil no Brasil, porém, para a assinatura de um contrato havia exigência do alistamento militar que Prestes não dispunha. À necessidade de alistar-se somou seu interesse pela aviação, por isso Prestes alistou-se na Aeronáutica, onde disporia de um curso específico para mecânicos de aeronaves. Seus planos iniciais eram de passar um tempo na Força Aérea e depois seguir carreira na aviação civil. Mas a vida militar submeteu Prestes a outra convocatória: um de seus tios, também comunista, seguiu com ele até a sede do PCB para que "limpassem" seu envolvimento com a juventude pecebista. Destruíram sua ficha de filiação e Prestes saiu acreditando que isso "apagou qualquer traço meu dentro do partido" - o que pode não ter sido efetivo, conforme se verá. Ao término da missão, Prestes escutou a promessa de que um dia seria procurado pelo setor armado do PCB - promessa que mais adiante se cumpriria.

Assim, o ingresso de Prestes de Paula naquilo que ele entendia como "mundo adulto" ocorria com a sua profissionalização na carreira militar e consequente independência da família. O alistamento lhe permitiu, portanto, os primeiros passos no mundo do trabalho. Tal experiência a partir da vida militar se tornaria preponderante no seu futuro e lançaria bases para o desenvolvimento de características que o acompanharam a partir de então. A análise de Sabina Loriga sobre a relação entre os mundos do trabalho e a experiência militar inspira um olhar sobre a trajetória do personagem em tela. Loriga afirma que o alistamento militar é um marco de valor iniciatório: "O serviço militar sanciona o ingresso do indivíduo no mundo dos adultos (...) que assegura a emancipação econômica, afetiva e sexual do jovem", algo que se confirma na trajetória de Prestes e também pela leitura que ele fazia da própria história - como ficará mais claro adiante. ${ }^{8} \mathrm{~A}$ autora demonstra que o alistamento estava muitas vezes ligado à insatisfação com a dependência familiar e com a submissão à autoridade da família, sobretudo para os jovens que ainda não haviam ingressado nos mundos do trabalho. Segundo ela,

Para os jovens que conheciam o mundo do trabalho desde a infância e já tinham passado longos períodos longe da casa paterna durante a adolescência, o Exército representava só uma das etapas da própria emancipação individual, enquanto para os estudantes, que raramente contribuíam para a gestão econômica da família e saíam de casa bastante tarde, ele tinha um valor iniciatório fundamental: entre a família de origem e o matrimônio, entre a independência econômica e a escolha da profissão, estava o uniforme militar. ${ }^{9}$ 
Portanto, a relação entre o indivíduo e sua experiência militar é antes de tudo uma relação de trabalho que sofre profunda influência das experiências profissionais que antecedem o alistamento do indivíduo e que influenciará, por certo, as que o sucedem. No caso de Prestes de Paula, sua primeira atividade profissional - e praticamente única por toda sua vida - foi entre muros de quartéis e se estendeu por quase duas décadas. Com ela, Prestes desenvolveu a seu modo a influência política que recebeu da família.

\section{Formação militar}

Em julho de 1947, aos vinte anos de idade, Prestes de Paula ingressou como $3^{\circ}$ sargento na recém-inaugurada base aérea de São Paulo, em Cumbica. À intencional liquidação de seu registro no PCB, com o fito de protegê-lo ante possíveis perseguições, seguiu-se um longo afastamento de qualquer militância político-partidária. Os planos de servir na Aeronáutica apenas pelo tempo de se capacitar como mecânico de aeronaves aos poucos também se modificaram. Com a conclusão do curso, Prestes foi transferido para o Ceará, onde se conscientizou dos benefícios de que gozava sendo de um quadro efetivo da Aeronáutica. Sua experiência militar não foi forjada a partir de seu envolvimento em guerras internacionais ou civis, mas a partir de questões que envolviam o cotidiano da caserna - assim entendia ele.

Um de seus vizinhos na pensão em que alugava quarto em Fortaleza era funcionário do Banco do Brasil havia vinte anos e, segundo correção monetária feita pela memória do sargento, ganhava aproximados mil e duzentos cruzeiros mensais, ao passo que ele, com menos de uma década de serviço, percebia mil e quinhentos. A despeito de uma possível imprecisão nos valores, o que se vê de sua contabilidade memorialística é que o trabalho na Aeronáutica era rentável e o cativou em definitivo: "Eu não tinha nenhuma responsabilidade, eu era solteiro. Eu mandava uma parte para minha mãe, para minha família, mas eu vivia bem. Eu tinha carro, motocicleta. Eu só queria namorar", contabiliza Prestes. Em meados dos anos 1950, ele assentou relação estável com sua primeira esposa.

Como aponta Loriga, após vestir a farda, os jovens se encontravam numa situação de "fundamental liminaridade", vivenciando um rito de passagem, algo que Prestes parecia ter concluído após acumular alguns anos de serviço militar, quando ele passou a mandar dinheiro para a família e constituiu a sua própria, casando-se - não sem antes namorar bastante..$^{10}$ Sobre esse período, acrescenta: "Eu nunca mais tive contato com o partido". A narrativa retrospectiva de Prestes revela que a Aeronáutica oferecia para ele relevantes atrativos, nem sempre encontrados noutros serviços: boa remuneração e estabilidade, algo que, somado a algumas transferências pelo país, foi capaz de afastá-lo da militância comunista - mas não de uma experiência que o faria retornar a ela.

Seu depoimento, mais os primeiros registros de seu histórico militar, levam a crer que o jovem Prestes não tinha um perfil forjado desde cedo para a caserna, sugerindo que ele precisou de algum tempo para adaptar-se àquela vida, ao passo que aprendia com ela. ${ }^{11}$ Quando tinha apenas dois meses de serviço, seu superior o repreendeu por descuidos com asseio e foi desacatado pelo jovem: por essa

10 LORIGA. "A experiência militar", p. 35-6.

11 Histórico Militar de Prestes de Paula, Arquivo Edgard Leuenroth (AEL), Coleção Brasil Nunca Mais, BNM 493, fls. 1328-1337. Fonte usada ao longo do parágrafo e também no parágrafo seguinte. 
falta grave e dupla Prestes ficou detido por oito dias no quartel. Em março do ano seguinte, outra detenção de seis dias por faltar à revista diária da tropa. No final de 1950, foi repreendido por não comparecer a uma parada militar. Em princípios de 1952, já promovido a $2^{\circ}$ sargento, Prestes saiu bastante da linha. Consta em seu histórico que criou "desordens em sua residência incomodando a vizinhança em completo estado de embriaguez, desrespeitando as convenções sociais em lugar público" e ainda concorreu "para desarmonia entre colegas". Pagou dez dias por essa falta considerada grave.

Tais deslizes, como se percebe, não impediram suas promoções. Mesmo porque, entre uma queixa e outra, Prestes de Paula nunca deixou de perceber elogios dos superiores. Num deles, seu comandante classificou como excelente sua cooperação: trabalhou "arduamente mesmo fora do horário de expediente para que os aviões estivessem em condições de cumprir todas as missões". Em janeiro de 1955, Prestes conquistou as insígnias de $1^{\circ}$ sargento, com a garantia expressa de ter alcançado o posto não "por antiguidade", mas "por merecimento". É possível, portanto, que entre os demais colegas de tropa suas faltas não fossem uma particularidade danosa. Ou, ainda que o fosse, Prestes conseguia compensálas ao se esforçar em algumas tarefas importantes.

Em meados dos anos 1950, as queixas se reduzem quase a zero em seu histórico; elogios, por outro lado, se tornaram mais frequentes e eloquentes sinal de seu amadurecimento como militar. Essa aparente inflexão coincide com sua transferência para a região em que era construída a nova capital federal, Brasília, para onde Prestes foi enviado no início do governo Juscelino Kubitschek (1956-1961). De acordo com Prestes, que poderia escolher entre outros destinos, a transferência para Brasília se tornou atrativa por conta de bonificações salariais - critério sempre importante para ele. ${ }^{12}$ Durante a inauguração da capital, seu comandante considerou "valiosa [sua] contribuição" e "indispensáveis [seus] esforços". Noutra ocasião, por sua "brilhante demonstração de garbo e disciplina", o superior não poupou adjetivos: "Cumpre-me em complemento à manifestação do público presente, pelos aplausos recebidos, fazer aqui o elogio [a Prestes] que tomou parte naquelas paradas, contribuindo assim para firmar cada vez mais o conceito que desfruta o pessoal do nosso destacamento", gabou-se o superior, não só por Prestes, mas por todo o destacamento aplaudido. ${ }^{13}$

Quando acumulava mais de uma década na Aeronáutica, Prestes de Paula demonstrava ser um militar mais maduro e dedicado - e por certo mais realizado com o soldo de $1^{\circ}$ sargento. De acordo com seu depoimento, ele se considerava um militar que cumpria diariamente sua jornada, "um funcionário normal", nada além disso, segundo palavras do próprio. ${ }^{14} \mathrm{Na}$ última entrevista que concedeu em vida, Prestes contou que a curta passagem de Jânio Quadros pela Presidência da República em 1961, encerrada por uma inesperada renúncia, influenciou decisivamente sua trajetória como sargento. Em sintonia com sua versão, consta em seu histórico que até aquele ano Prestes "acha-se no bom comportamento". A partir de então, elogios e pequenos deslizes deram espaço quase exclusivamente às anotações de um inquérito militar a que responderia. ${ }^{15}$

Seu relato sobre as consequências da renúncia de Quadros condensa bastante uma sucessão de eventos que parecem ter ocorrido entre 25 de agosto, dia da renúncia,

12 Entrevista de Prestes de Paula, 4 ago. 2001. Fonte usada ao longo do parágrafo e também no seguinte.

13 Histórico Militar de Prestes de Paula, BNM 493, fls. 1328-1337.

14 Entrevista de Prestes de Paula, 4 ago. 2001.

15 Histórico Militar citado, BNM 493, fls. 1328-1337. 
e 5 de setembro, dia do desembarque de João Goulart em Brasília. O relato recupera as tensões daquela conjuntura e também ilustra as complexas relações entre oficiais e praças, como eram chamados os subalternos das Forças Armadas (sargentos, cabos e soldados) e, sobretudo, o entendimento de Prestes sobre os eventos.

De acordo com Prestes, as notícias da renúncia de Jânio Quadros o atingiram com surpresa: ele estava às vésperas de gozar de uma licença e pretendia passar um tempo pescando na região do Araguaia, distante da rotina militar. ${ }^{16}$ No entanto, a insegurança política gerada pela renúncia e pela posse iminente do vice Goulart mobilizaram os oficiais da base aérea de Brasília, suspendendo sua licença. O contingente de homens naquela base era de duzentos e oitenta praças e cinquenta oficiais, segundo sua estimativa, e enquanto estes últimos se opunham unanimemente à posse de Jango, os praças formavam uma maioria "apática", de acordo com seu olhar retrospectivo. Numa noite, por ser o sargento mais antigo da tropa, Prestes recebeu do oficial de plantão o encargo de sargenteante. Segundo ele, o sargenteante é quem "aperta, que faz a disciplina, controla, que faz chamada" - note-se que, de acordo com sua versão, o encargo foi recebido a partir de critérios verticais. Em seguida, a tropa foi despertada para se apresentar em forma, o que incluiu armas em punho. Sequer o sargenteante sabia o que estava acontecendo, até que receberam a informação que iriam para a vila militar fazer guarda nas residências dos oficiais.

Prestes cria dois eixos para explicar a radicalização que viria. "Alguém me disse: poxa, por que os oficiais têm guarda e nossas famílias lá no centro da cidade não têm?", ouviu de um par. Ao receber a queixa, ele colocou em prática outra função que lhe cabia: além de disciplinar a tropa, o sargenteante deveria também levar suas demandas aos de cima - mesmo nomeado de cima para baixo, ele precisava corresponder aos anseios de seus pares subalternos. Assim, reportou a questão ao tenente, que lhe retransmitiu as palavras do comandante: famílias de oficiais moravam dentro da base e não seria possível deslocar tropas para atender às famílias dos subalternos, que residiam fora da base e dispersas pela cidade. Houve réplica do sargenteante, mas o superior recorreu ao regulamento para encerrar a conversa: para o comandante tratava-se de um argumento não apenas estratégico, mas também respaldado pelas regras da disciplina militar, por isso os sargentos receberiam punições em caso de descumprimento. Para Prestes, era típico exemplo das "contradições entre os postos" - ou uma questão de classe -, registrou anos depois.

O segundo pretexto para a dilatação do conflito na base aérea, de acordo com o relato de Prestes, foi a circulação de informações externas. Pelo rádio, ele escutou de Leonel Brizola o chamado para resistir ao golpe em curso, o que o fez tomar conhecimento sobre as intenções golpistas dos oficiais. "Esse negócio calou fundo, a gente era muito doutrinado do ponto de vista da Constituição, da legalidade", rememorou Prestes, que percebia nisso um convite à insubordinação. "Eu tava completamente despreparado, nem pensando em assumir militância nem nada, mas eu tava muito tocado pela tentativa de golpe. Eu achava que tinha que defender o presidente da República, eleito constitucionalmente. Eu tinha uma formação muito legalista". O depoimento de Prestes se compromete com uma versão que o aproxima mais dos interesses da sua categoria e dos princípios legalistas do que com eventuais diretrizes comunistas ou partidárias.

Assim, a convergência do desconforto com as diferenças entre patentes, a iminência de punição e a possibilidade de golpe gerou um debate entre os

16 Entrevista de Prestes de Paula, 4 ago. 2001. Usada ao longo do parágrafo e também na página seguinte. 
sargentos. Prestes conta que a possibilidade de sublevação nunca foi consensual: os mais jovens preferiam a rebeldia, os mais velhos não pretendiam arriscar seus postos, mas de acordo com ele, poucos praças desistiram da sublevação. Esse foi o contexto que legitimou o sargenteante Prestes - que já não era um jovem, tinha 34 anos - a prosseguir no motim, liderando uma maioria de subalternos suficientemente afinados. Os passos seguintes culminaram no desmonte da Operação Mosquito, algo que segundo Prestes só foi descoberto no decorrer do levante, "a gente tinha ouvido falar, mas a gente não tinha certeza". A operação, organizada por oficiais conservadores, pretendia abater o avião em que o vicepresidente retornava ao Brasil da China comunista ou forçá-lo a pousar com fito de impedir sua posse. ${ }^{17} \mathrm{O}$ sucesso da insubordinação legalista, segundo memórias de Prestes, fez com que os sargentos recebessem cinquenta convites para participar da posse do novo presidente como "convidados de honra". "Fomos assistir fardados à posse dele", garante Prestes. ${ }^{18}$

O seu envolvimento nesse motim não contou como queixa em seu histórico. Mas inaugurou nova etapa em sua trajetória militar já como líder entre os sargentos - mas não por muito tempo. A partir dessa data, apenas uma reprimenda foi anotada em seu histórico. Prestes cometeu uma infração considerada média por "ter frequentado lugar incompatível com o decoro da classe, portando arma de fogo e feito disparo". Nas horas de folga, ele podia não vacilar quanto ao decoro condizente com sua "classe". E aquilo que aos superiores parecia indecoroso, por vezes servia como aproximação entre os praças.

\section{O fuzil como instrumento de trabalho}

No início da década de 1960, dois sargentos que serviam em Brasília (um da Aeronáutica, outro dos Fuzileiros Navais) entraram em disputa por mulher quando aproveitavam sua folga longe do serviço. No conflito, o fuzileiro matou o colega de patente a tiros e terminou preso. Nias Fernandes, sargento fuzileiro, encarregava-se de escoltar o preso quando foi procurado por um praça do Exército e Prestes de Paula. Segundo Nias, eles o abordaram para assuntar sobre "a necessidade dos sargentos terem um clube que pudessem frequentar, pois o baixo meretrício e certas boates não eram ambientes para eles". Prestes garantiu que ele e o companheiro do Exército comungavam da ideia de "criarem um clube que congregasse todos os sargentos que servissem em Brasília, independente da Arma" e que idealizavam um grêmio "apolítico, sendo apenas beneficente e recreativo". De acordo com Nias, que compôs o conselho deliberativo do clube, aquela não era bem uma novidade: "Os outros sargentos também conversaram a respeito de tais propósitos". ${ }^{19}$

17 Para outras versões sobre a Operação Mosquito, ver SILVA, Hélio. 1964: golpe ou contragolpe. Rio de Janeiro: Civilização Brasileira, 1975, p. 144-145 e ROSE, R. S. The unpast: elite violence and social control in Brazil, 1954-2000. Ohio University, 2005, p. 33-34 (traduzido e publicado pela editora Companhia das Letras em 2001 como Uma das coisas esquecidas. Getúlio Vargas e controle social no Brasil, 1930-1954). Para este assunto vale também conferir RIDENTI, Marcelo. O fantasma da revolução brasileira. São Paulo: Unesp, 1993, p. 209 e PARUCKER, Paulo. Praças em pé de guerra: o movimento político dos subalternos militares no Brasil (1961-1964) e a Revolta dos Sargentos de Brasília. São Paulo: Expressão Popular, 2009. Durante a escrita do texto, dificuldades de acesso ao livro obrigaram a utilização de sua primeira versão, PARUCKER, Paulo. "Praças em pé de guerra. O movimento político dos subalternos militares no Brasil, 1961-1964". (Dissertação de mestrado em História, Universidade Federal Fluminense, 1992).

18 Entrevista de Prestes de Paula, 4 ago. 2001.

19 Depoimento de Nias Fernandes, 12 out. 1963. BNM 692, fls. 708. 
A ocasião de um conflito capital entre sargentos em sua hora de folga era oportunidade para a categoria refletir sobre as condições a que estava submetida, mas não apenas nas horas de folga. Segundo o mencionado estudo de Loriga, a experiência militar vivida por jovens europeus era intensamente marcada pela guerra ou por sua constante iminência, mas no caso de Prestes de Paula, sua experiência parece ter sido definida pelas relações de trabalho verticalizadas dos quartéis e pelo cotidiano militar (hierarquias, salários, condições de vida e serviço, etc.) - relações que não silenciavam diferenças de classe.

Após intervenção dos sargentos de Brasília em favor da posse de Jango, o prestígio da categoria se ampliou e, como demonstram fontes policiais e o depoimento do próprio Prestes, ele pôde assuntar sobre a necessidade de organização não apenas entre pares. Ele recria um diálogo direto que teria estabelecido com o presidente, por quem fora recebido para tratar de sucessivas transferências que atingiram os sargentos depois da insubordinação em 1961. No Palácio do Planalto, Prestes teria ouvido do seu notável interlocutor: "Eu estou aqui graças a vocês" e por isso não perdeu a oportunidade para pedir apoio para a fundação do clube que almejava para a categoria. Segundo sua versão, Jango perguntou: "É uma sociedade civil?", e como Prestes confirmou positivamente, ouviu: "Então registre". ${ }^{20}$

As memórias de Prestes sobre o trânsito que ele e sua categoria alcançaram após a sublevação de 1961 - talvez superlativizadas - explicam de alguma maneira o valor que o sargento atribui a esse episódio e as consequências dele na sua trajetória. Para Parucker, "a primeira aparição do movimento dos sargentos na conjuntura 1961-1964, para o grande público, foi relativamente modesta, quase uma 'curiosidade'", mas, para Prestes, o episódio parece ter imenso valor. ${ }^{21}$ Segundo ele, "aí começa a minha atividade política" e uma etapa importante da história dos sargentos, afastados de vez da "apatia" de antes.

Com a preeminência conquistada por Prestes de Paula à frente dos sargentos, ele chamou atenção do PCB e recebeu a visita prometida pelo tio quinze anos antes: um tenente o procurou para identificar-se como membro do $\mathrm{PCB}$, não sem antes certificar-se: "Vocêé sobrinho do seu Afrânio?". Prestes recebeu a recomendação de contatar outro oficial no Rio de Janeiro e restabelecer laços no partido, costurandoos por dentro das Forças Armadas - vínculos interestaduais que àquela altura não atendiam apenas aos interesses do partido, mas também aos sargentos. De acordo com Gorender, o PCB era pouco aceito entre os sargentos. ${ }^{22}$ Parucker estende às Forças Armadas em geral a mesma resistência: "Sua penetração enfrentava o estigma que sobre o comunismo se construiu durante décadas, mormente no seio das Forças Armadas". Para Parucker, partido e correntes políticas estavam diluídas entre os sargentos, "mesmo que elas seguissem atuantes de forma mais ou menos organizada, o faziam nos limites dos seus círculos restritos: nenhuma conseguiu impor-se hegemonicamente ao movimento a ponto de poder proporcionar uma identificação exata de sua presença". 23 Portanto, a condição de classe dos sargentos superava diferenças e unificava o grupo para além de princípios políticopartidários - filão que o PCB pretendia explorar.

Os contatos de Prestes no Rio de Janeiro respeitavam uma lógica que não

20 Entrevista de Prestes de Paula, 4 ago. 2001. Fonte usada nos parágrafos seguintes.

21 PARUCKER. "Praças em pé de guerra", p. 38.

22 GORENDER, Jacob. Combate nas Trevas. A esquerda brasileira: das ilusões perdidas à luta armada. $3^{\mathrm{a}}$ edição. São Paulo: Ática, 1987, p. 49.

23 PARUCKER. "Praças em pé de guerra", p. 83. 
devia ser puramente partidária. Parucker demonstra também que naquele período, não apenas em Brasília, mas em outros estados do país, havia uma significativa tendência à fundação de clubes, nem sempre inspirada por experiências de insubordinação como em Brasília. ${ }^{24}$ Ainda em 1961, os praças da capital federal fundaram seu clube, tendo Prestes como presidente. No ano seguinte, os sargentos do Rio de Janeiro fundaram o seu, e em 1963 foi a vez de os soldados e cabos instituírem um clube específico em Brasília. Assim, o PCB devia estar acompanhando o interesse crescente dos praças por organização e nisso Prestes poderia se tornar um aliado.

De acordo com Parucker, os clubes pretendiam atender a inúmeras demandas, "sua criação estava sempre associada a reivindicações como assistência médico-hospitalar, jurídica, educacional, recreativa e financeira, entre outras". ${ }^{25}$ Para Prestes, "era na verdade um sindicato, só tinha aquela capa. O que a gente discutia lá eram outras histórias (...). Eles transferiam um cara, nós íamos atrás e verificávamos se realmente o sargento era uma pessoa sóbria, porque às vezes o cara também era desordeiro. E a gente não ia se queimar". Inicialmente engajados contra transferências, eles passaram a reivindicar a elegibilidade dos sargentos para cargos no Legislativo, direito que apenas os oficiais gozavam. Sua busca por organização e representação política coincidiu com o aumento das tensões do período que antecedeu ao golpe civil-militar de $1964 .^{26}$

Jorge Ferreira mostra que temas encapados pelos sargentos na eleição de 1962 encontraram respaldo fora das fileiras militares, quando a quantidade de votos recebida por um sargento, que desbancou nas urnas o general Juarez Távora, "demonstra que ele não foi eleito apenas pelos sargentos, mas também por outras categorias de trabalhadores". ${ }^{27}$ A questão da elegibilidade envolveu os sargentos numa crescente radicalidade, em especial os de Brasília, na medida em que os sargentos no Rio de Janeiro conseguiram ampliar vínculos com outros setores sociais. ${ }^{28}$ Alguns eleitos foram impedidos de tomar posse e outros que chegaram a se empossar tiveram mandatos suspensos por decisão judicial de primeira instância. A questão seria decidida pelo Supremo Tribunal Federal (STF), sito justamente à capital federal. De acordo com Prestes, o tema da elegibilidade tocava na cidadania dos sargentos e a causa unificou os praças:

Era uma tropa única: Exército, Marinha, Aeronáutica e Polícia. Os sargentos eram unificados em torno do clube e o presidente do clube era eu. E todo mundo tinha uma confiança em mim, eu tinha muita liderança porque eu era muito caxias, eu não vacilava. ${ }^{29}$

Prestes se reconhece como liderança dos sargentos na medida em que representava interesses coletivos. Da mesma maneira que garantiu que não seria conivente com sargentos que não apresentassem comportamentos corretos, como demonstrado linhas atrás, ele não trairia a categoria que o respaldava. Ocupando a Presidência do clube, ele teria recebido uma proposta de transferência consentida para servir numa missão da ONU no Congo com inúmeros benefícios materiais,

24 PARUCKER. "Praças em pé de guerra", p. 38.

25 PARUCKER. "Praças em pé de guerra", p. 86.

26 Para contextualização resumida sobre o movimento dos sargentos, ver LAMARÃO, Sérgio. "A Revolta dos Sargentos". Verbete, Dicionário histórico-biográfico brasileiro, CPDOC/FGV.

27 FEEREIRA, Jorge. "A estratégia do confronto: a Frente de Mobilização Popular". Revista Brasileira de História, São Paulo, v. 24, n. 47, p. 187.

28 FEEREIRA. "A estratégia do confronto", p. 195-196.

29 Entrevista de Prestes de Paula, 4 ago. 2001. Fonte usada no parágrafo seguinte. 
mas dessa feita os benefícios não foram suficientes para convencê-lo: "Eles estavam lidando já com um comunista, não era mais um cara qualquer", reivindica ele, identificando o que para ele era seu retorno definitivo à militância comunista. Se o mote dos sargentos durante as campanhas era "sargento também é povo", após a cassação dos mandatos seu mote passou a lembrar que o "instrumento de trabalho do militar é o fuzil". ${ }^{30}$ Prestes convocou os sargentos para uma assembleia e propôs: "Agora é a hora. O que vocês acham: a gente não faz nada ou a gente levanta os quartéis e toma a capital? Militar não faz greve: militar ou faz revolução ou rebelião".

Não cabe aqui uma narrativa sobre o levante que se seguiu à decisão do STF confirmando a cassação dos mandatos, já que a pesquisa de Parucker é bastante precisa nisso e o fez concluir que Prestes de Paula "foi o líder assumido e inconteste do levante". ${ }^{31}$ Inspirados pela contrariedade do STF à sua causa, os sargentos de Brasília partiram para a estratégia do protesto armado, desfraldado sob argumento pretensamente revolucionário. Tanto Parucker quanto Ferreira concluem que o levante enfraqueceu o movimento e, junto com ele, seu líder "assumido e inconteste". Parucker encontrou recorrentes depoimentos de envolvidos no levante que demonstram profunda animosidade para com Prestes de Paula após o fracasso do levante. Um sargento preso foi taxativo em sua repreensão:

A medida mais acertada a seu ver, segundo pôde sentir de seus próprios colegas a bordo do navio presídio 'Raul Soares', foi não terem ali colocado também o sargento Prestes, pois tal era a revolta em que todos se achavam possuídos quanto ao procedimento desse sargento, que talvez se ali estivesse não viesse a sobreviver. ${ }^{32}$

O levante dos sargentos encerrou o período em que Prestes esteve mais entrosado socialmente, cercado por pares que se dispunham a ouvi-lo, confiavam nele e o seguiram em mais de uma ocasião. Mas o insucesso de sua disposição para o conflito converteu-se em profunda condenação não apenas no terreno jurídico, mas também entre os seus. Após o levante, Prestes foi preso, mas experimentou breve momento de liberdade condicional, quando aproveitou para estabelecer contatos no $\mathrm{PCB}$ - decerto já sem muito trânsito entre sargentos. Nas reuniões que participou, algumas no Rio de Janeiro inclusive, descobriu que "as posições do partido estavam muito mais à direita que às minhas (...) eu estava para ir pro caminho armado e o partido estava naquela de que o caminho da revolução tinha que ser pacífico".33 Com isso, Prestes se distanciava não apenas dos praças, mas também do $P C B$.

Duas semanas após o golpe de 1964, ele foi encarcerado de vez e em setembro desligado da Aeronáutica. Nesse período, seu envolvimento em atividades suspeitas aos olhos dos superiores fez com que seu nome constasse em solicitação de uma auditoria militar formada para investigar subversivos. ${ }^{34} \mathrm{Nela}$ consta que Prestes "foi arregimentado para a campanha eleitoral de 1947 pelo PCB, no qual ingressara em 1946, sendo estruturado na célula Félix Aguero": fracassara, portanto, a tentativa de apagar, anos antes, o envolvimento do jovem Prestes com a juventude comunista. A veiculação de tal dado no referido relatório, ausente no

30 PARUCKER. "Praças em pé de guerra", p. 51.

31 PARUCKER. "Praças em pé de guerra", p. 89. Sua descrição sobre o levante se concentra no capítulo 5.

32 PARUCKER. "Praças em pé de guerra", p. 172.

33 Entrevista de Prestes de Paula, 4 ago. 2001.

34 Relatório, 5 nov. 1964. BNM 6, fls. 1368. 
histórico militar de Prestes, é indício de que seu vínculo juvenil com o PCB pode nunca ter interessado aos superiores que nunca o desabonaram por suspeitas vermelhas, sendo despertados para essa relação apenas quando Prestes tomou parte em insubordinações. O posto de liderança que Prestes de Paula alcançou à frente dos praças em Brasília não se repetiria em nenhuma outra fase de sua vida, quando Prestes de Paula deixou de representar qualquer categoria profissional e onde ele transitou estimulado apenas por princípios político-ideológicos.

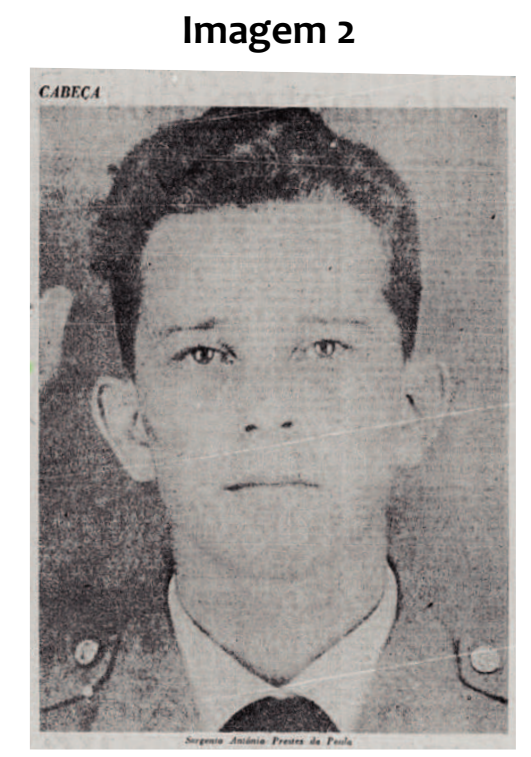

Foto do sargento Antônio Prestes de Paula publicada no Jornal do Brasil, Rio de Janeiro, 14 set. 1963. Na legenda da foto aparece uma alusão a Prestes ser o líder do levante.

\section{Nova articulação intramuros}

Prestes cumpriu pena no Conjunto Penitenciário Frei Caneca, no Rio de Janeiro, onde conviveu com outros subalternos da Marinha, presos também por subversão, e com criminosos condenados pela legislação comum. De acordo com Cátia Faria, desse convívio diversificado surgiu "um caso exemplar de intercâmbio e entrelaçamento entre presos políticos e comuns e/ou bandidos e revolucionários", uma associação incomum que deu origem ao Movimento de Ação Revolucionária (MAR). ${ }^{35}$ Ex-militares de dentro e também de fora da prisão fundaram o MAR inspirados por ideias nacionalistas e com planos de instaurar um foco guerrilheiro de luta armada. ${ }^{36}$ Mas para aquele núcleo de presos a formação de um coletivo que garantisse sua fuga era uma etapa imediata e necessária à revolução vindoura.

Mais uma vez, Prestes precisou se relacionar não somente com "superiores" - nesse caso guardas, funcionários, médicos -, já que seu objetivo ali, a fuga, dependeria também de relações estabelecidas com seus pares ali. Porém, se tratavam de pares que se aproximavam em torno de princípios que não respeitavam critérios laborais: na fuga, concretizada em maio de 1969, havia seis presos políticos e três comuns. ${ }^{37}$ Para isso, foi fundamental conquistar colocação em postos

35 FARIA, Cátia. "Revolucionários, bandidos e marginais. Presos políticos e comuns sob a ditadura militar". (Dissertação de mestrado em História, Universidade Federal Fluminense, 2005), p. 59-60.

36 GORENDER. Combate nas Trevas, p. 125. Mais informações sobre o MAR aparecem em TAVARES, Flávio. Memórias do Esquecimento. São Paulo: Globo, 1999.

37 De acordo com o relatório de fuga, junto com Prestes escaparam os ex-militares Antônio Duarte dos 
estratégicos, como faxineiros, ajudantes no consultório médico ou na biblioteca. Tais postos possuíam vagas reduzidas, já que também eram "estratégicos" para quem não pretendia a fuga. Segundo Faria, havia muitos "candidatos dispostos inclusive a pagar por elas" e "os presos políticos não fugiram à regra; pagaram todas as vezes que foi preciso"..$^{38}$ Mesmo essa monetarização dos postos não bastou para alocar nos postos-chave todos aqueles que pretendiam escapar. Alguns presos não se dispunham a vender suas colocações, enquanto outros preferiam costurar alianças - horizontais, entre presos, ou verticais, com as autoridades do presídio. Assim, os interesses ideológicos, em prol do MAR, e os mais concretos, pela fuga, convergiram.

Para explicar os laços pessoais e políticos que resultaram na formação do MAR e na fuga subsequente, Prestes de Paula alega certa proeminência ao papel dos presos políticos dentro do presídio: "Nós não queríamos a divisão, nós queríamos ficar no meio [dos demais presos]. A gente alfabetizava. Tinha alguns sargentos que eram técnicos em eletrônica e começaram a dar cursos", destacando ainda a importância de atender às expectativas dos "superiores". "Além disso, a gente mantinha uma disciplina com relação aos regulamentos da casa que não dava trabalho. Os guardas gostavam da gente e os presos também gostavam da gente". Conforme registra o sargento, a biblioteca do presídio tinha vários livros marxistas, livros "difíceis" que "ninguém lia, era tudo empoeirado", que então começaram a circular e ser discutidos, "e aí [a gente] foi puxando alguns presos comuns, pessoas que tinham ideias mais ou menos de esquerda". ${ }^{39}$ Mas a adesão aos princípios de esquerda nem sempre foram determinantes para coesão do grupo.

Os ex-militares se associaram com quem podiam e os presos comuns sempre negociaram seu ingresso no grupo. Um primeiro preso comum foi incorporado por demonstrar alguma "consciência", mas estabeleceu condição para seu ingresso: só aceitaria o convite se um companheiro seu, com quem já traçava planos de fuga, o acompanhasse. Os presos políticos aceitaram, afinal, se eles tinham interesses próprios, os outros presos também possuíam uma ética que não pretendiam romper. O último a entrar no grupo, mesmo sendo conhecido matador, não pôde ser dispensado, foi incorporado, explica Faria, "para impedir que outro grupo de presos, do qual ele era o líder, executasse um plano de fuga que tinha poucas chances de êxito", o que chamaria atenção para planos afins em andamento..$^{40}$ Assim o grupo de fuga foi constituído de modo a respeitar os interesses de todos os envolvidos e nem sempre em pleno acordo com cartilhas marxistas.

O diretor do presídio, por sua vez, entendeu que os presos políticos comandaram a fuga, que "só logrou êxito, graças ao auxílio externo com que contaram os evadidos", relatou menosprezando as articulações estabelecidas entre presos, intramuros e horizontais..$^{41} \mathrm{O}$ diretor sabia de aproximações suspeitas entre presos políticos e comuns e que profissionais do presídio estavam sendo cortejados - outro preso servia como informante do diretor, decerto em troca de benefícios. Por isso ele solicitou sem sucesso a transferência do interno Willian da Silva Lima, condenado por furto e que "mantinha junto com seus companheiros pregação político-ideológica contrária aos princípios democráticos", relatou

Santos, Avelino Bioen Capitani, Benedito Alves Campos, José Adeildo Ramos e Marco Antonio da Silva Lima; José André Borges, José Michel Godoy e Roberto Cieto, os três condenados por furto.

38 FARIA. "Revolucionários, bandidos e marginais", p. 62.

39 Entrevista de Prestes de Paula, 4 ago. 2001.

40 FARIA. "Revolucionários, bandidos e marginais", p. 65-67.

41 Relatório, 3 jun. 1969, BNM, 414, fls. 22-23. Usado no parágrafo seguinte. 
o diretor. Willian, mais adiante conhecido como "professor", não seguiu os companheiros que fugiram, nem tampouco aderiu ao MAR. Ele já era um detento antes de chegarem os presos políticos e seu relato sobre essa convivência chama atenção, especialmente por contradizer o papel que Prestes se atribui à frente dos presos comuns.

"Nunca tive vulgo 'professor', foi a polícia que colocou", afirma Willian em recusa à pecha policial e distinguindo-se de outros criminosos. ${ }^{42}$ Descreve também o que foi para ele a relação com os presos políticos: "Quando chegaram (...) eles conviveram com a massa (...) eles assimilaram a teoria nossa, que eles não conheciam a teoria de esquerda, eles eram simplesmente sindicalistas, eram rebeldes, mas tinham um modo de viver comum". Portanto, a literatura marxista existente na prisão desde o Estado Novo pode também ter balizado as relações apontadas por Willian, que não hesita em afirmar sua agência na relação com os presos políticos a partir, inclusive, dos mesmos critérios a que eles recorrem: a preponderância intelectual. André Borges, um dos presos comuns que se juntou à fuga, confirma isso: "Já havia uma 'cultura política' na prisão, herdada dos presos políticos do Estado Novo". ${ }^{43}$ Ou seja, os livros que Prestes descreve como empoeirados e difíceis de ler podiam não ser tão inacessíveis assim. Além de eventuais teorias consultadas, Willian descreve o cotidiano intramuros:

Começamos então a formar um grupo de estudo e eles [os presos políticos] se integraram a esse grupo de estudo. E também a uma convivência mais produtiva. Eles faziam bolsa, eles faziam material artesanal. E quando a repressão chamou eles, como o sargento Antônio Prestes de Paula, que era a liderança, e Marco Antônio da Silva Lima (...) para separar, eles disseram que eram massa. Eles não quiseram se separar. Eles queriam conscientizar mais a massa através do trabalho, através das coisas concretas.

Willian da Silva Lima não fugiu junto com Prestes, nem ingressou em projeto de luta armada revolucionária. Em meados dos anos 1970 sua dedicação a "coisas concretas" o fez ingressar no Comando Vermelho como um de seus fundadores. Em seu livro de memórias reafirma a importância do contato com Prestes de Paula e com o marinheiro Marco Antônio Lima em sua formação. ${ }^{44}$

Prestes e Willian enxergam sob perspectivas distintas a influência mútua que exerceram sobre si, e as relações entre os grupos que ambos representam são bastante controversas. Após conviver com duas gerações distintas de presos políticos, Willian explica: "Quando eu fui para a Ilha Grande, já era outro tipo de preso político. Os presos intelectuais da classe média, da pequena burguesia, que eram os grupos armados, que eram imediatistas, e isso eu já sabia (...) eles achavam que eram organizados; quem era organizado, éramos nós". 45 Dentro dos presídios, Willian passou a conviver com outro perfil de militantes; fora dela, após sua fuga, Prestes também. Assim como Willian, o ex-sargento passou a conviver com outro perfil de companheiros, bem distante da inserção social de que dispôs no começo da década, quando representava o clube dos sargentos e liderava os subalternos de Brasília. Isso exigiria de Prestes certa capacidade de adaptação.

42 Depoimento retirado de SOUZA, Caco (diretor). "Senhora Liberdade". Documentário: 2004. Disponível em: https://www.youtube.com/watch?v=-ICHgA93XhQ. Usada no parágrafo seguinte.

43 FARIA. "Revolucionários, bandidos e marginais", p. 63.

44 LIMA, William da Silva. Quatrocentos contra um. Uma história do Comando Vermelho. $2^{\text {a }}$ ed. São Paulo: Labortexto Editorial, 2001.

45 SOUZA. "Senhora Liberdade". 


\section{Imagem 3}

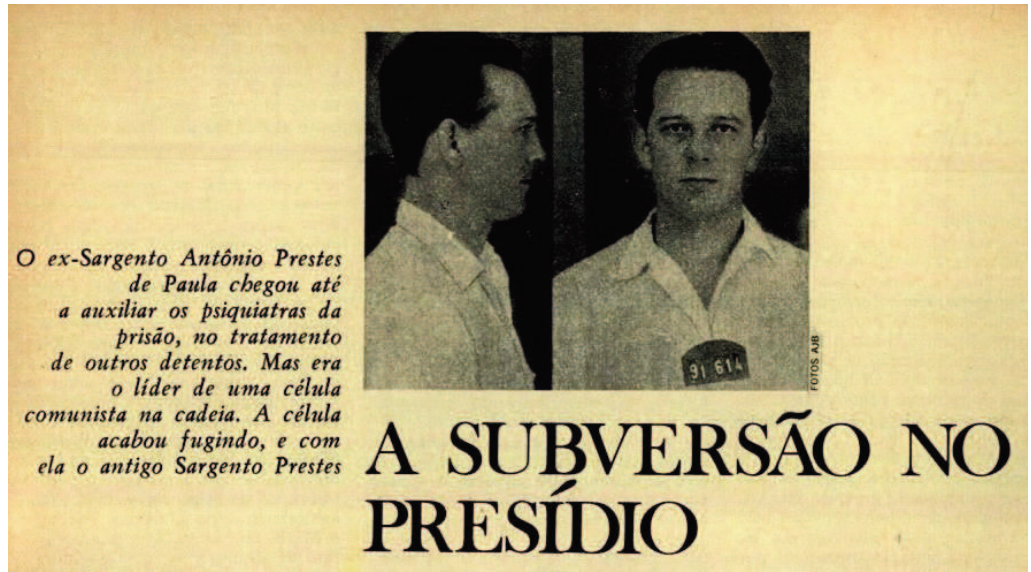

Detalhe de reportagem de Veja, São Paulo, 4 jun. 1969. Após a fuga de 1969, Prestes aparece na reportagem como líder do episódio. Depoimentos de outros presos relativizam sua preponderância.

\section{Experiências na resistência à ditadura}

A existência do MAR foi breve: alguns assaltos e uma rápida tentativa de implantar o foco guerrilheiro na região de Angra dos Reis (RJ) que sacramentou seu fim. Além da curta existência, Marcelo Ridenti aponta outras características marcantes desse grupo: possuiu muitos ex-militares em suas fileiras e por isso foi atípico no tocante à idade de seus membros, cuja média passava dos trinta anos. ${ }^{46}$ Quando Prestes entrou em contato com outros membros da organização - mais jovens -, ele percebeu que sua idade poderia não significar prestígio: "Avaliaram que a minha idade ia ser um trambolho. Eu tava com quarenta e quatro, quarenta e cinco anos, mas o pessoal era muito rígido porque o Guevara disse que o ideal era 25 anos". ${ }^{47}$ Por isso não quiseram os mais jovens que Prestes atuasse na frente rural da guerrilha planejada. Fora da cadeia e sem insígnias de militar, Prestes experimentou outros conflitos, talvez compensados pelo passado de militar, mas já era notório que o prestígio que desfrutou à frente do clube dos sargentos não era mais o mesmo. Os vínculos dos mundos do trabalho que entrosaram Prestes entre os militares não valiam naquelas organizações paramilitares e sua idade podia se tornar um "trambolho".

Segundo Loriga, o Exército "não foi sempre um interlocutor específico da juventude, tampouco um espaço ocupado exclusivamente por machos jovens". Ela cita exemplos de crianças e anciãos que tomaram parte em fileiras militares: "Durante muito tempo, a idade dos recrutas teve pouca importância: quem quisesse podia alistar-se. O que contava, no momento do engajamento, era o aspecto físico"..$^{48}$ Loriga chega a falar em ocasiões em que os exércitos até preferiam recrutar homens mais velhos para contornar a indisciplina dos mais jovens, porém não eram esses os critérios dos exércitos revolucionários e clandestinos dos jovens inspirados por Guevara na segunda metade do século XX. Ao alistar-se nessas organizações de esquerda, Prestes experimentou alguma resistência. 
O MAR teve vida breve e muitos de seus integrantes foram assassinados ou presos. Entre os poucos que sobreviveram e continuaram suas atividades estavam Prestes e outros ex-militares, todos balzaquianos experimentados nas armas. Com a desintegração do MAR, eles se alistaram no PCBR, uma organização que tinha em suas fileiras nomes de prestígio entre as esquerdas como Apolônio de Carvalho, Mário Alves e Jacob Gorender e pregava a revolução popular com o proletariado rural e urbano na dianteira, onde a guerrilha rural teria papel de destaque - desde sua fundação vinculara-se ao marxismo-leninismo. ${ }^{49}$ O PCBR não dispensava a organização partidária nesse processo, por isso incorporou à sigla do PCB o adjetivo de Revolucionário, "do qual viria a qualificação distintiva", de acordo com Gorender. ${ }^{50}$

Segundo Prestes, quando eles e os outros militares chegaram ao PCBR, a organização "não tinha feito ainda nenhum assalto". Com humor, ele acrescenta: "Todo mundo fazendo assalto e o PCBR se sentia meio desprestigiado, tava com a autoestima muito baixa porque não conseguia fazer um assalto, porque só tinha estudante". O humor de Prestes não esconde que ali sua idade não era problema, ao contrário: sua experiência militar poderia compensá-la e ele usaria sua disposição para as ações armadas como um cartão de visita na nova organização. ${ }^{51}$ No PCBR, Prestes encontrou terreno fértil para desenvolver seus planos revolucionários e armados. Pessoalmente ele parece ter se encontrado nessa organização, da qual não mais se desfiliaria. E para isso contribuiu a aceitação daquilo que Prestes representava e passou a representar ainda mais: um ex-militar com disposição às armas.

A partir do segundo semestre de 1969, o PCBR estava mesmo premido por seus membros para acelerar sua participação na luta armada e com ex-sargentos da Aeronáutica e da Marinha a bordo isso poderia ser resolvido. Considerado em atraso na prática dessas ações, seus dirigentes chegaram anunciar à militância um assalto a banco antes mesmo de sua execução, contrariando medidas primordiais de segurança, como revela Marco Aurélio Garcia. ${ }^{22}$ Segundo Gorender, o militarismo do PCBR era uma "pressão vinda sobretudo do pessoal do Nordeste", que após sucessivas quedas envolvendo o Comitê Central se firmou no comando da sigla. No novo Comitê Central já não estavam nem Apolônio de Carvalho, nem Mário Alves, nem Jacob Gorender, mas o pernambucano Bruno Maranhão, que ascendeu à direção do grupo num encontro realizado na Bahia. ${ }^{53}$ Nesse encontro, Prestes se tornou comandante militar do PCBR - o mesmo posto que ocupava quando participou dos assaltos a banco na Bahia na década de 1980.

A presença de Prestes no PCBR e sua passagem pela Bahia aparecem bem narradas no livro de Sandra Silva. ${ }^{54}$ Prestes fora deslocado para a Bahia, junto com outros dirigentes nacionais, para fugir da repressão policial mais intensa na região Sudeste. Em Salvador, algumas ações foram planejadas, como o sequestro de um cônsul e um assalto a banco, mas tais não aconteceram ou se frustraram. No caso do

49 Para a fundação do PCBR, ver GORENDER. Combate nas trevas, p. 101-106; GARCIA, Marco Aurélio. "O PCBR: da formação à tentação militarista". Em Tempo, ano III, n. 93, dez. 1979 e "O PCBR na agonia do militarismo". Em Tempo, São Paulo, ano III, n. 94, dez. 1979; DELLA VECHIA, Renato da Silva. "Origem e Evolução do Partido Comunista Brasileiro Revolucionário (1967-1973)". (Dissertação de mestrado em Ciência Política, Universidade Federal do Rio Grande do Sul, 2005).

50 GORENDER. Combate nas trevas, p. 102.

51 Entrevista de Teresa Notari, 24 maio 2012.

52 GARCIA, Marco Aurélio. "O PCBR: da formação à tentação militarista". Em Tempo, ano III, n. 93, dezembro/1979.

53 GORENDER. Combate nas trevas, p. 102.

54 SILVA, Sandra. Ousar lutar, ousar vencer: histórias da luta armada em Salvador (1969-1971). Salvador: Edufba, 2013. 
banco assaltado, eles terminaram chamando atenção da polícia, ocasionando novas quedas. Nessa fase, a organização vivia uma crise originada pela clandestinidade e pela alta repressão policial. Na Bahia, o PCBR não conseguiu escapar à repressão nem atrair uma quantidade de simpatizantes que tornassem seus planos viáveis: se a ditadura era um entrave incontornável, seu projeto revolucionário também podia ser pouco atrativo. Assim como outras organizações armadas desse período, o PCBR minguou após um grande isolamento social, somado à intensa e crescente repressão policial. ${ }^{55}$

Pouco tempo depois, Prestes de Paula deixou o Brasil autoexilado e esta pesquisa dispõe de reduzidas referências sobre esse período de sua vida. Em depoimento, ele revela que passou pelo Chile, de onde pretendia retornar ao Brasil para reingressar na resistência armada, e em seguida pela França, de onde retornou ao Brasil nos anos 1980 já com o rosto modificado por uma cirurgia plástica. ${ }^{56}$ Mesmo distante, não deixou de atrair atenção da polícia brasileira. Um informe confidencial produzido pela Polícia Federal em novembro de 1980 contava a história de uma Junta de Coordenação Revolucionária, criada em 1975, com envolvimento de inúmeras organizações comunistas do Cone Sul. ${ }^{57}$ Era um grupo de fomento à luta armada no qual se integrava o fragmentado PCBR. ${ }^{8}$ Entre seus membros constavam Fernando Gabeira, Apolônio de Carvalho e Prestes de Paula - no documento, seu nome aparece destacado vermelho. O informe parece dar muita credibilidade ao grupo, que tinha um "potencial econômico" de 60 milhões de dólares, "embaixadas" em diversos países da Europa e América Latina, além de traficar armas entre o Novo e o Velho Mundo, afirmaram os policiais.

\section{Retorno em ambiente de redemocratização}

Logo que retornou ao Brasil, anistiado em 1980, Prestes morou em Recife, onde contava com uma rede de relações oferecida por Bruno Maranhão. Segundo Prestes, enquanto seus antigos companheiros de caserna se aproximavam do PDT, fundado por Brizola, ele preferiu se engajar na construção do Partido dos Trabalhadores. ${ }^{59}$ Simultaneamente, Prestes recompôs laços no PCBR, reassumindo seu comando militar, com Maranhão no Comitê Central da organização. Nos termos da militância da época, Prestes e Maranhão passaram a vestir duas camisas: uma do PT, outra do PCBR.

Mais uma vez Prestes conviveu em Recife com militantes de novas gerações bem mais jovens que ele. ${ }^{60}$ Mesmo com cabelos embranquecidos por seus 53 anos, não raro disfarçados por matizes louros artificiais, Prestes despertou atenção especial na companheira Teresa Notari. E Teresa lembraria depois que não era aquela a primeira vez que o via:

55 Um panorama das organizações de esquerda desse período pode ser encontrado em REIS, Daniel. A revolução faltou ao encontro: os comunistas no Brasil. São Paulo: Brasiliense, 1990.

56 Entrevista de Teresa Notari, 24 maio 2012.

57 Informe, 11 nov. 1980. Arquivo Público do Estado de São Paulo (APESP), DEOPS, 50 e 33, 3416 a 3423.

58 Segundo o documento, compunham a Junta: Movimiento de Izquierda Revolucionaria (Chile), Ejército Revolucionario del Pueblo (Argentina), Ejército de Liberación Nacional (Bolívia) e Tupamaros (Uruguai). Do Brasil compunham-na: Ação Nacional Libertadora, Movimento Revolucionário 8 de Outubro e também o PCBR.

59 Entrevista de Prestes de Paula, 4 ago. 2001.

60 Maiores detalhes sobre o retorno de Prestes de Paula ao Brasil, incluindo sua relação com outros militantes, aparecem mais detalhados em TORRES. "A questão financeira é uma questão política", p. 39-50, 53-60. 
Eu tinha conhecido o velho Prestes quando eu era uma menina [anos 1970]. Um pouco mais que adolescente, no início da minha juventude. O Velho estava clandestino em Olinda (...) E eu conheci o Velho numa ciranda. Ele era um homem muito sedutor, realmente. Ele me encantou já ali. E foi assim, uma passagem muito rápida, até porque ele não podia se expor. ${ }^{61}$

Em seu retorno, a idade de Prestes não parece ter sido um problema. Era chamado de "Velho" sem constrangimentos por Teresa e outros companheiros. Ele e Teresa também iniciaram um romance apaixonado: para ela, vinte anos mais jovem, era o reencontro com seu ideal de militância; para ele, ocasião de recompor novo relacionamento, já que seu primeiro casamento não resistira à prisão e ao exílio. Sem se empregar formalmente, Prestes viveu esses anos como militante profissionalizado no PCBR, recebendo da organização módicos proventos. Por isso, Prestes não se demorou em Pernambuco: em 1981 migrou para São Paulo acatando a uma decisão que não era genuinamente pessoal. Nessa fase, dando prosseguimento à paixão, Prestes e Teresa trocaram inúmeras cartas reclamando do distanciamento e traçando planos de reencontro. Entre uma carta e outra, com muitas declarações de saudades, Teresa transmitiu recado de Bruno Maranhão para Prestes:

Ele acha que teu círculo de amizade não deve ficar restrito à colônia nordestina. Diz que deves ter um relacionamento mais amplo, lembrando ainda a importância de um aprofundamento na amizade com Lula, visto teres tido uma boa relação com ele quando esteve aqui. ${ }^{62}$

O PCBR dos anos 1980 disputava espaço com outras tendências do Partido dos Trabalhadores e o acesso a seu principal líder poderia facilitar suas relações, por isso a presença de Prestes em São Paulo pode ser exemplo da sua importância no PCBR. E o sargento Prestes era diligente em suas tarefas: após o assalto de Salvador, em 1986, Lula, que então presidia o PT, precisou explicar publicamente porque Prestes constava entre seus seguranças na campanha ao governo do Estado em 1982 - um tipo de vínculo comprometedor depois de Prestes ser vinculado a assaltos a banco. À Folha de São Paulo, Lula defendeu-se alegando "que o pessoal encarregado de sua segurança variava muito de comício para comício", mas - não podia negar - se lembrava da presença do ex-sargento. ${ }^{63} \mathrm{E}$ se, pelo visto, Prestes foi bem sucedido nas intenções de se garantir próximo a Lula, não deixou de protagonizar momentos anedóticos na função de segurança que lhe coube. $O$ sindicalista Djalma Bom recorda que durante tensão em um dos comícios de Lula, Prestes teria sido o primeiro a correr. ${ }^{64}$

61 Entrevista com Teresa Notari, 23 maio 2012.

62 Carta de Teresa Notari para Prestes, 15 nov. 1981. Processo 860372816, Salvador, Fórum Rui Barbosa, $7^{\text {a }}$ Vara Crime, v. 7, fls. 463. Doravante citado apenas como "Processo".

63 Folha de São Paulo, São Paulo, 23 abr. 1986.

64 FERREIRA, Marieta de Morais; FORTES, Alexandre (orgs.). Muitos caminhos, uma estrela: memórias de militantes do PT. São Paulo: Editora Fundação Perseu Abramo, 2008, v. 1, p. 96. 


\section{Imagem 4}

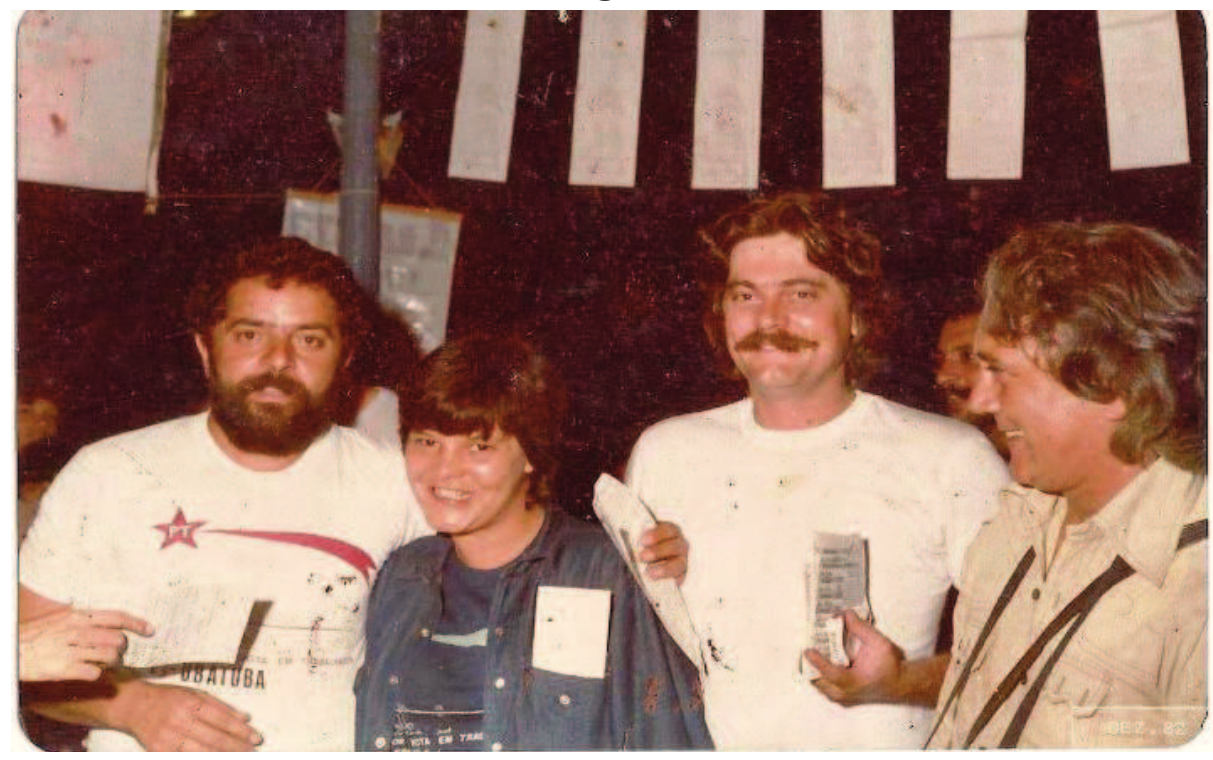

Foto do acervo familiar de Antônio Prestes de Paula, dezembro de 1982. Na fotografia aparecem Lula, candidato ao governo de São Paulo em 1982, e na outra extremidade, à direita, o ex-sargento Prestes, de perfil, com cabelos aloirados e mirando o candidato petista. De acordo com recomendações do dirigente Bruno Maranhão, Prestes deveria "aprofundar" a amizade com Lula.

Em 1983, Teresa migrou de Pernambuco para São Paulo com seus dois filhos e ela e Prestes passaram a viver juntos novamente. Teresa empregou-se na CUT, enquanto Prestes seguia profissionalizado no PCBR. Segundo Teresa, isso acontecia "de uma forma muito discutida, muito tranquila, sem nenhum problema". ${ }^{65}$ Então, Prestes se aproximou do movimento dos desempregados de São Paulo, vestindo as camisas do PT e do PCBR. Ao ser preso, em 1986, ele disse que se aproximou do grupo "pois sentia que ali (...) iria aprender de estruturação e organização de movimento" e reconheceu que "em face do seu passado como ex-militante do PCBR, exilado em Paris (...) conseguiu angariar simpatia". ${ }^{66}$ Em setembro de 1983, ele esteve à frente de algumas centenas de desempregados que acamparam no Parque do Ibirapuera por quase dois meses, e liderou uma ocupação ao Serviço Nacional de Emprego (SINE), órgão ligado ao Ministério do Trabalho, em 1984, dando visibilidade à luta de trabalhadores sem serviço.

Nesses anos, Prestes de Paula também se dedicou intensamente a uma atividade pela qual nunca foi reconhecido: a produção de textos. Embora Prestes sempre tenha sido um homem mais ligado à prática da militância política, alguém com "visão bem militarista do processo" - para ele, Lênin era "o dono da bola" -, e considerasse seu conhecimento teórico razoável, sua disposição à máquina revela um redator dedicado. ${ }^{67}$ Ele elaborou análises de conjuntura e de suas experiências, críticas contra diretrizes partidárias, atas de encontros, cartas pessoais e outros tantos manuscritos - em grande parte legados à pesquisa histórica após sua prisão em 1986, quando uma devassa foi feita em sua residência por policiais que apreenderam tal material. A análise dessas fontes abundantes exigiria um espaço que transbordaria os limites do texto - já elastecidos pela vida longeva do personagem em tela -, mas para o que interessa à compreensão de sua trajetória,

67 Entrevista de Prestes de Paula, 4 ago. 2001. 
vale mencionar um tema revelado nessa documentação: a exacerbação de seus planos revolucionários e os conflitos que eles lhe causaram.

Os conflitos experimentados por Prestes entre os desempregados paulistas ilustram as diferenças que tornavam o PCBR uma tendência cada vez mais isolada dentro do PT e o ex-sargento aparece como personificação de tais diferenças, datilografadas por ele em muitos textos que registram seu cotidiano. ${ }^{68} \mathrm{Em}$ um texto posterior ao acampamento do Ibirapuera, Prestes criticou as lutas sindicais por suas "concepções pelego-reformistas": "Quando dizemos que a prática sindical tem um caráter econômico não queremos chegar ao absurdo de negar que a luta sindical é também uma luta política, mas que dentro dos sindicatos a luta política não é o aspecto determinante". Para o militante em tempo integral - que já não era liderança de qualquer categoria - as lutas sindicais não sanavam as demandas mais importantes das classes trabalhadoras. Por isso, Prestes identificava no movimento dos desempregados um potencial revolucionário, dada a "facilidade com que as massas desempregadas rompem com a legalidade existente e imposta pelas classes dominantes". Entendia ele que "quando o estômago ronca de fome, entram em crise os valores sociais que até hoje serviram de freio ideológico para conter o descontentamento popular".69

Prestes antevia uma crescente para os desempregados, que culminou com a ocupação do SINE em 1984. Numa ata de reunião em que os ocupantes analisaram a experiência não faltaram críticas aos líderes do grupo - e Prestes era um deles. ${ }^{70} \mathrm{Um}$ dos ocupantes reclamou que os coordenadores imaginaram que ficariam ali apenas por um dia, pois esperavam confronto imediato com a polícia. "Na verdade, depois da ocupação, o que foi que ocorreu?", perguntou, "nós ficamos mais dias, [disseram] que haveria repressão no primeiro dia, mas não houve. Eles [o governo] usaram outra estratégia conosco". À espera de um conflito direto com o poder público que não aconteceu, os ocupantes ficaram no prédio sem água e energia, sem colchões, cobertores, mantimentos, etc. Outro ocupante disse que a fome que ele passou enquanto esteve no SINE não o incomodou, "porque eu passo fome em casa", mas seu incômodo era com as infiltrações que aumentavam a repressão contra eles: "Não tenho aqui minha cara para ser quebrada à toa", asseverou. A queixa desses ocupantes revela o descompasso que Prestes experimentava ali: o velho sargento seguia apostando na tática da dilatação de conflitos diretos com Estado e patrões para acelerar a revolução que ele pretendia. E nisso distanciava-se daqueles que preferiam outras formas de luta e sobrevivência. Após a ocupação, O Estado de S. Paulo provocou o seu destacado líder dizendo estranhar que Prestes de Paula "até hoje não se inscreveu no SINE para arranjar um emprego". ${ }^{71}$

Pouco depois, Prestes registrou descontente num rascunho seu: "Sete meses de refluxo, o SINE foi em agosto do ano passado". ${ }^{72}$ Ao contrário da crescente que ele previra, o movimento dos desempregados viveu um refluxo nesse período: segundo Ana Maria Doimo, a ocupação do SINE foi a última grande mobilização pública dos desempregados paulistas que viveram completo esgotamento em

68 A presença de Prestes de Paula entre os desempregados de São Paulo e as relações entre o PCBR e o PT aparecem mais detalhadas em TORRES. "A questão financeira é uma questão política".

69 Documento "Movimento de luta contra o desemprego - uma proposta para discussão", dez. 1983. Processo, v. 7, fls. 394-410.

70 "Balanço da invasão do SINE", 1984. Processo, v. 7, fls. 520-523. Fonte usada ao longo do parágrafo.

71 Estado de S. Paulo, s/d. Processo, v. 7, fls. 515.

72 Manuscrito de Prestes de Paula, fev. 1985. Processo, v.7, fls. 411. 
1986. ${ }^{73}$ Sintomaticamente, enquanto o movimento dos desempregados refluía, o PCBR investia aceleradamente nos assaltos: foram três, entre 1984 e 1986, e Prestes esteve no comando de todos eles. Com essas ações armadas de financiamento, a organização buscava compensar seu isolamento social, algo que o PCBR experimentava em nível nacional e Prestes de Paula entre os desempregados paulistas. As relações entre o PCBR e o PT estão desenvolvidas de maneira mais profunda na minha dissertação. ${ }^{74}$

A estratégia do conflito adotada por Prestes, assim como aconteceu quando esteve à frente dos sargentos, não Ihe trazia bons resultados. Dias antes de viajar para Salvador, onde comandaria o malfadado assalto a banco de 1986, Prestes escreveu para sua companheira e esposa, Teresa. A carta possui um tom seco e seu objetivo era cobrar dela maior empenho no PCBR. Sem peias, Prestes revela o papel que atribuía ao PT, ao PCBR e à CUT, onde Teresa trabalhava com dedicação excessiva, segundo o marido. Prestes reclamou da atenção de Teresa à CUT "porque dilui a olhos vistos o teu compromisso com a O." - leia-se, o PCBR. ${ }^{75}$ Dividida entre a jornada profissional na CUT e a militância no PCBR, Teresa não atendia ao gosto de Prestes, que repreendeu a esposa - repetia-se, assim, o Prestes rigoroso dos tempos de sargenteante. Prestes comparou Teresa com um companheiro que também militava no PCBR e na CUT: "Toda a tua crítica contra o Benjamim", redigiu, "apesar de justa, se exacerba porque ele representa o teu oposto em relação à CUT. Ele simplesmente caga solenemente para ela". E concluiu: "Tens a consciência da importância desse instrumento revolucionário [o $\mathrm{PCBR}$ ], sem o qual a CUT não terá a menor consequência estratégica".

É evidente que Prestes acreditava com muito mais vigor naquilo que o PCBR representava na década de 1980 e que isso o deixava cada vez mais isolado. Seus escritos revelam a permanência de vínculos com princípios marxista-leninistas e seu nítido distanciamento dos mundos do trabalho. Enquanto Prestes demonstrou compreender melhor a experiência de trabalho dos sargentos sendo um deles, conseguiu despontar como liderança representativa da categoria. Após radicalizar suas demandas no levante em Brasília, ele se afastou em definitivo de experiências que lhe garantiam maior entrosamento em ambientes coletivos. Isolado, primeiro na cadeia, depois na vida clandestina, Prestes de Paula se aprofundou em princípios teóricos revolucionários que não foram capazes de lhe permitir acesso aos movimentos sociais da forma como ele queria: agora não mais como um membro de uma classe ou categoria, mas como comandante de uma vanguarda. Sua rápida aproximação dos desempregados paulistas e sua tentativa de militar paralelamente no PT e no PCBR revelam isso.

Ao analisar os pressupostos de organizações vanguardistas como o PCBR, Daniel Reis cita a revolução socialista, "redentora do proletariado", que aparece inevitável em seus planos, e a "imprescindibilidade do partido de vanguarda, intérprete qualificado do devir histórico". Para ele, entre essas organizações é comum "que se conheça melhor as peripécias das revoluções já ocorridas do que as particularidades da história do próprio povo"..$^{76} \mathrm{E}$ como atestam as práticas e os planos de Prestes de Paula para os desempregados de São Paulo, também Ihe faltava um olhar mais acurado sobre as particularidades do movimento. Prestes

73 DOIMO, Ana Maria. A vez e a voz do popular. Movimentos sociais e participação política no Brasil pós-70. Rio de Janeiro: Relume Dumará/ANPOCS, 1995, p. 109-110.

74 TORRES. "A questão financeira é uma questão política".

75 Carta de Prestes para Teresa, mar. 1986. Processo, v. 7, fls. 393.

76 REIS, Daniel. A revolução faltou ao encontro: os comunistas no Brasil. São Paulo: Brasiliense, 1990, p. 182-183. 
de Paula demonstra que o PCBR dos anos 1980 guardava traços típicos de sua primeira formação, quiçá universal às vanguardas leninistas revolucionárias e, principalmente, que ele era um quadro bastante ilustrativo da geração de militantes formada nelas - fossem jovens de classe média ou ex-militares acima dos trinta anos.

\section{Conclusão}

Em entrevista à Brasil Revolucionário, quando ainda cumpria pena pelo assalto de 1986, Prestes anunciou autocríticas, reconhecendo que o assalto "se deu numa conjuntura imprópria" e que cometeu "um erro de avaliação política". 77 Mesmo assim, ele insistiu: "O assalto foi um erro porque não deu certo". Ou seja, não fosse o insucesso da ação, Prestes revela que ela poderia não ter sido a última e que para ele, portanto, não se tratava de uma prática ilegítima. Considerou que não era "menos verdadeiro que do ponto de vista ideológico; a nossa atitude em Salvador não negou os interesses fundamentais das classes trabalhadoras", pensava ainda em 1992, apegado aos mesmos princípios que abraçara entre as décadas de 1960 e 1970. O fracasso do assalto fez com que os militantes envolvidos nele fossem expulsos do PT e exauriu as condições de o PCBR se manter como uma tendência no partido, praticamente desaparecendo depois disso. ${ }^{78}$

Às vésperas das eleições de 1994, quando acreditava que Lula se elegeria pelo Partido dos Trabalhadores, Prestes anotou em um caderno com apontamentos para textos posteriores que a esquerda tornava-se incapaz de responder aos desafios da luta de classes por não responder à questão sobre como "compatibilizar as ações legais com as ações ilegais da revolução" - assim como seu quase homônimo, Luís Carlos Prestes, o sargento nutria o hábito de muitas anotações cotidianas. ${ }^{79}$ Para ele,

Justamente agora, face à perspectiva da eleição de Lula em 1994, que promete ferir a fundo os interesses do grande capital e do latifúndio, as forças revolucionárias deveriam estar se preparando para defender o governo popular contra o latifúndio e a burguesia (...) não se trata de dois partidos como alternativas politicamente diferentes disputando uma proposta para os trabalhadores. Mas são dois partidos que cumprem papéis diferenciados, ocupando espaços distintos e que pretendem ser complementares.

Para Prestes, é inegável que a defesa dos interesses das classes trabalhadoras exigia um partido formado por quadros dispostos às armas e à clandestinidade. A essa altura, Prestes afastara-se de vez da experiência de classe que viveu na Aeronáutica e apegava-se exclusivamente ao militarismo que a caserna pode inspirar. Depois de cumprir pena na Bahia, Prestes foi morar no Paraná e se reaproximou do PT, inclusive ministrando cursos de formação de militantes sobre o que esta pesquisa dispõe de pouquíssimas informações. Em 2004, Prestes de Paula faleceu na cidade de Cascavel (PR).

77 Revista Brasil Revolucionário, São Paulo, ano III, n. 10, maio/jun./jul. 1992. Fonte usada no parágrafo seguinte.

78 Entre os envolvidos no assalto consultados durante essa pesquisa, há divergência quanto à continuidade do PCBR no PT: alguns apontam que tal continuidade foi construída pela sigla Brasil Socialista, outros a negam.

79 Caderno de Prestes de Paula. Acervo familiar. 
Dentro do espaço reduzido dessas páginas, foi possível reconstruir brevemente a trajetória de Antônio Prestes de Paula, apresentar parte das experiências que ele acumulou ao longo de sua vida e as variadas maneiras como ele se relacionou com sujeitos distintos. A observação de sua trajetória demonstra seu processo contínuo de formação, transitando por diferentes espaços sociais e por conjunturas de intensa instabilidade democrática - algo que sem dúvidas contribuiu severamente para os rumos que ele trilhou e para muitas de suas escolhas. Enquanto pôde fazer uso regular de suas insígnias de sargento, adquiridas paulatinamente e sem atalhos, Prestes de Paula desfrutou de um entrosamento social que não se repetiu em sua trajetória. Quando elas passaram a servir como mera representação de seu passado militar, elas não foram capazes de suplantar o seu isolamento: quanto maior sua adesão a princípios ditos revolucionários, menos respaldo social ele alcançou; quanto mais ele perdeu tal entrosamento, mais militarista ele se tornou.

As notícias do envolvimento de Prestes no assalto de Salvador em 1986 motivaram uma declaração de um antigo companheiro seu, que pretendia defender Prestes da acusação de ser um infiltrado. Ele e Fernando Gabeira conviveram durante o exílio de ambos na Europa, e aos olhos de Gabeira, Prestes de Paula era um sujeito teimoso, não um traidor:

Existe um dos presos que é meu amigo, eu o conheço bem (...) atribuiuse a ele o fato de ser da polícia, de ser um provocador e tal, mas não creio não, ele é apenas uma pessoa teimosa; ele continua achando que o caminho é esse e eu acredito que vai continuar achando algum tempo, até... É uma pessoa teimosa, eu diria: 'Você é uma pessoa teimosa!'. Mas o que eu tenho a dizer a ele é que o caminho não é esse; é pessoa que admiro pessoalmente, ele não é pessoa má, apenas teimosa. ${ }^{80}$

Prestes, por sua vez, defendeu-se da acusação de ser um novo cabo Anselmo, garantindo "ter dez vezes mais potência que Anselmo para destruir a esquerda", sugerindo que seu entrosamento era muito mais profundo que o do famigerado cabo delator. ${ }^{81} \mathrm{Se}$, de fato, dispunha de tanto poder, não se sabe, mas a pecha de infiltrado parece excessiva para o ex-sargento. A pecha de teimoso, por outro lado, parece mais oportuna.

Recebido em 27/07/2016

Aprovado em 01/01/2017

80 Fernando Gabeira, entrevista no programa Roda Viva, 22 dez. 1986. Disponível em: http://www.rodaviva. fapesp.br/materia/248/entrevistados/fernando_gabeira_1986.htm.

81 Folha de São Paulo, São Paulo, 28 jun. 1986. 